\title{
QUANTITATIVE DECISION MAKING IN LAND BANKING: A MONTE CARLO SIMULATION FOR CHINA'S REAL ESTATE DEVELOPERS
}

\author{
Haijun BAO ${ }^{1}$, Alain Yee-Loong CHONG ${ }^{2} \stackrel{凶}{ }$, Hongdi WANG ${ }^{3}$, Liyuan WANG ${ }^{4}$ \\ and Yikun HUANG ${ }^{5}$ \\ ${ }^{1}$ College of Business Administration, Zhejiang University of Finance \& Economics, Hangzhou, \\ China \\ ${ }^{2}$ Department of Industrial and Systems Engineering, Hong Kong Polytechnic University, Hong \\ Kong, China \\ ${ }^{3}$ Department of Real Estate and Construction, University of Hong Kong, Hong Kong, China \\ ${ }^{4}$ College of Business Administration, Zhejiang University of Finance \& Economics, Hangzhou, \\ China \\ ${ }^{5}$ Department of Real Estate and Construction, University of Hong Kong, Hong Kong, China
}

Received 21 September 2011; accepted 17 February 2012

\begin{abstract}
The real estate industry is one of the fast growing industries in many developing countries such as China and India. The Chinese real estate industry has gone through many reforms from offering housing as part of its social welfare system, to the current capitalist model based on demand and supply. Due to these reforms and the shortage of lands for development in China's urban cities, many Chinese property firms have resorted to land banking in order to secure land property for future developments. However, in China, land speculation is considered illegal, while failure to purchase the suitable land for future developments will hinder the real estate developers' future business and growth. The purpose of this paper is to develop a decision making model for property developments in their land banking decisions and strategies. The paper employed mathematical modeling and Monte Carlo simulation to examine our decision model, and further validated our results by conducting the simulation by using China Vanke Co. Ltd as a case study. This study is one of the first few studies that develop a decision model for land banking in China. It also helps real estate enterprises to make rational and dynamic decision in the current dynamic property market.
\end{abstract}

KEYWORDS: Land banking; Real estate enterprise; Decision model; Monte Carlo simulation; China

\section{INTRODUCTION}

The rapid urban growths in countries such as China and India have resulted in heavy demand for housing and land. A country's state of housing has an important direct impact on its public health and an indirect effect on the labour productivity through general morale of workers (Lee, 1988). The issues related to urban housing such as the lack of land is faced by almost every developing nation (Juškevičius, 2003) including China (Lee, 1988; Zax, 1997). Similar to many developing countries, the government will tackle the issues of urban housing by selling land for developers, and allow developers to build private housing to cope with the rising demand for the 
urban population (Zavadskas et al., 2005). Although China is similar to many developing countries in issues related to land and housing, it is also faced with a new challenges as China had an institutional housing arrangements in the past, and only moved towards allowing private real estate developments in the late 1990s (Zhang et al., 2009; Zhang et al., 2011).

Prior to the "Reform and Open Policy" in 1978 , there was no private urban housing market in China, and the provision of urban housing was a part of the socialist welfare system. Even after 1978, the reform of the distribution of Chinese welfare housing still progressed slowly because of the continuing debate on the cession of state-owned land and workerowned housing (Wu, 1996). In the 1980s, real estate development was merely a quasi-form of housing delivery, in which the development of housing was through specialized real estate enterprises which were not independent market participators. This type of development was called "comprehensive development" because the real estate enterprises developed the housing for the enterprises (Wu, 2001). Up to the mid-1990s, the reform of urban housing system underwent several critical changes. The nationwide establishment of an urban Housing Provident Fund (HPF) in 1994 was an important policy to facilitate the transition of housing from a welfare item to a commodity. After 1995, China instituted the urban commercial housing transaction market in almost every city (Chen et al., 2011). Housing reform enabled state enterprises to withdraw from direct housing production; however, housing consumption was still subsidized and allocated through the state work-units (Wu, 1996; Wang and Murie, 1996). In 1998, under the support of the former premier of China - Zhu Rongji, a new housing policy was formulated. The new housing policy stated that by the end of the 1998, the welfare housing provision system characterized by in-kind allocation would be abolished and replaced by the housing provision through real estate markets. As a result of the new policy, China's urban housing reform completed the revolutionary transition from a state-sponsored welfare housing provisioning system to an open commodity housing market in this critical decade. With the transition, China is today one of the most active and fast growing real estate markets (Leung et al., 2011).

With this major conversion of the housing delivery system, the number of real estate enterprises in China increased quickly. Land use rights are remarkably important to the developers and they have to apply and obtain the approval from the government authorities. Land reform began in 1988 when the Chinese government approved the clause which contained "the right to use land may be transferred in accordance with law" (Wu, 2001). The change in the system of land use is however, less dramatic, as most land is leased through negotiations rather than open biddings or auctions (Yeh and Wu, 1996). Therefore, the land use right is allocated to developers of real estate by the government authorities based on a government imposed land-price framework that does not adhere to market principles. This decision for the allocation of land no longer follows the economic principles which are so often adhered to in the capitalist market. However, once a property is developed, the property is then transacted between the developers and buyers based on the prevailing market price. Therefore there exists a double-track price system for the land acquisition, and in the housing market, and the double-track price system favors the developers over the public in general. The profits of the developers mainly derived from the allocated land use rights and the developers will therefore always try to obtain the land use rights of the maximum amount of land.

The lack of transparency in obtaining land use rights became a major obstacle to cultiva- 
tion of a true land market value, and it leads to rent-seeking, corruption, windfall profits and loss of the state-owned assets (Wu, 2001). In order to eliminate these phenomena, the Chinese government's ministry of land and resources implemented regulations on the transfer of land use rights by bid or auction in 2002. As for 2004, the Chinese government prohibited the negotiations on land transfers between property developers and the government, and all the sales of land for real estate projects were transferred to market biddings or auctions. After that, the double-track price system for land purchase and housing market disappeared gradually. Faced with the uncertainties in the land and housing market, developers which have traditionally enjoyed the windfall profits in the initial stage of land reform were confused on the quantity of land banking. Land banking refers to the advance acquisition and reservation of land before development (Tu et al., 2008). Overpayments for land lead to not only financial risks, but also tremendous policy risks for land speculation, as land speculation is prohibited by the Chinese government. On the other hand, a lack of land banking will affect the sustainable development of the real estate developers, and weaken their competitiveness. The issue with how to balance the quantity of land banking is an important decision to the developers in China. However, despite the issues faced by the Chinese property developers due to the changed from land acquisition system, few theoretical and practical researches have been developed to help them make decisions and formulate strategies on land banking decisions. Various decision models have being applied in the study of real estate in recent years (Kaklauskas et al., 2007). The aim of this paper is to examine the decision criteria involved in land banking, and developed a quantitative approach for helping firms to make appropriate land banking decisions. Monte Carlo simulation is applied to test the proposed de- cision model. The application of the method was also demonstrated through conducting a case study on a Chinese property development firm - China Vanke Co. Ltd. This paper proceeds by providing some background on land banking. The next section provides an original research model for private developers and an overview of the Monte Carlo simulation method, followed by a case study. The paper then concludes with discussions on the implications of the research.

\section{LITERATURE REVIEW}

Land banking is defined as the advance acquisition and reservation of land before development. The concept of land banking was first initiated in Amsterdam in late 1890s. Land banking was also adopted by several western countries such as Sweden (since 1904), Canada (since 1950's) and France (since 1958) during the last century (Atmer, 1987; Carr and Smith, 1975). Since the 1970's several pilot projects of public land banking were carried out in some American cities as well (Huang, et al., 2002).

Existing literatures on institutional framework and practice of public land banking in western countries have summarized the key functions that land banking can achieve: control on urban growth pattern, capturing capital gains for public finance, and land price regulation (Flechner, 1974; Strong, 1979; Enders, 1986; Evans, 2004; Van Dijk and Kopeva, 2006). Generally, land banking practices can be viewed as a tool for the government to intervene land market for the purpose of growth management and plan implementation.

Recent researches showed that public land banking approach are initiated in some developing countries. In central Europe, such as Bulgaria and Hungary, public land banking is being practiced to solve the problem of fragmentation of agricultural lands (Van Dijk and Kopeva, 2006). In Zimbabwe, a public land banking process named "land resettlement" is 
used to control social tensions arising from imbalanced distribution of resources, local overpopulation, unemployment and involuntary displacement in the past (Harts-Broekhuis and Huisman, 2001). Some Southern Asian cities including India and Bangladesh are also currently implementing lank banking policy (Huang, 2010).

Land banking was introduced in China during the 1990's. Some cities, such as Shanghai and Hangzhou began to establish the mechanism of land banking in 1996. Land banking mechanism is now widely practiced in over 1,600 cities or counties in China. The booming practice of land banking arouses research interest of scholars in China. Some researchers have also introduced western experience and put forward many proposals for the problems arousing with the implementation of public land banking in China (e.g. Ma, 2003; Wang, 2004; Yang, 2006; Fan et al., 2009). Quantitative decision methods for land banking by government agencies were put forward. The methods include supply restricting, cost minimizing and profit maximizing (Zeng, 2006). Land banking organizations in China act in the double status between enterprises and government agencies. The land bank, guided by public interests, primarily aims to enhance the comprehensive benefit of urban land to the greatest extent. Moreover, it has to take the urban running status into account, especially the financial goals of local governments, while maximizing economic profits (Tu et al., 2008).

From the above, it can be seen that existing researchers mainly focused on the public land banking. However, there are two categories of land banking including land banking by the public representatives, and land banking by private land development enterprises (Evans, 2004). Although the land banking organizations in China partly act as enterprises, their decisions on the land banking are different from private land development enterprises. Private enterprises mainly focus on the eco- nomic profits, while the government focuses on both social benefits and economic profits. Another difference is in the acquisition of land. The private enterprises purchase land use rights by bid or auction in the primary land market, while the government acquires land through expropriation.

Recently, some literatures focused on the land banking by private land developers. Liu and Ren (2008) pointed out that the behavior of developer's land banking is determined by the economic conditions; and the developers will balance the holding costs and the anticipated earnings when making decisions on the quantity of land banking. The loan interest rate and financing ability have influence on the land banking behavior of developers in holding cost, while the anticipation on the future housing price increase and uncertainty of future market have influence on the land banking behavior of developers in the anticipated earnings. Wang (2008) concluded that the cycle of real estate, the growth stage of enterprise and periods of development influence the quantity of land banking. Zhu (2009) probed into the effect of land banking on performance of real estate enterprises and maintained that there exists an optimal quantity of land banking. Nevertheless, these literatures are merely appreciating the qualitative analysis.

Tse (1998) developed a qualitative decision model to optimize land banking for enterprises based on the Hong Kong environment. In his model, it is assumed that the land market is highly competitive because the land is sold by public auction. Based on the general equilibrium theory he concluded that the developer's optimal amount of land banking occurs when the expected marginal return of land holdings equals the rate of interest. However, the model lacks practical insights for private land developers. Gimpelevich (2011) on the other hand, laid out a practical method for stochastic quantitative risk management modeling based on an application of Monte Carlo simulation for 
real estate development projects. It inspires to build a practical method based on an application of Monte Carlo simulation for private developers.

Therefore, in order to bridge the gaps in existing literature, this research aims to develop original quantitative methods for private developers and it will contribute new insights to the existing literature.

\section{RESEARCH MODEL AND METHODOLOGY}

\subsection{The process of land banking}

According to the theory of inventory management (Peterson and Silver, 1979), land banking is the inventory for private land development enterprises. System of land banking inventory includes purchase of land use right, land banking and land development (see Figure 1).

\section{Purchase of land use right}

Since the Chinese government's ministry of land and resources implemented regulations on the transfer of land use rights in 2002, private land development enterprises have purchased land use rights by bid or auction in the primary land market. Because of the quota control of agricultural land transferring and the government basic policy in land sales, which is similar to Hong Kong' s policy to sell land to the highest bidder at public auctions, the price of land use right in China is sharply upward. The price of land use right is the most sensitive to the enterprises.

\section{Land banking}

Sun (2007) compared the development strategies between Chinese real estate enterprises in the A share market and those in Hong Kong Stock Market. He found that an obvious differences in the development strategies between real estate enterprises in Hong Kong Stock Market and China's A share market is that Hong Kong firms made more pursuit of land banking amount with a financial structure of high cash and low debt, and the real estate enterprises in the A share market tend to choose development speed oriented strategies. Sun (2007) also regarded that the development speed oriented strategies go well with the specific situation in China, especially conforming to China's existing land development policy, and thus is more possible to provide Chinese real estate enterprises attractive return. In the mode of development speed oriented strategies, the lands purchased by the developers are never stationary, and instead they are in a liquid process of "pursue-develop-sale".

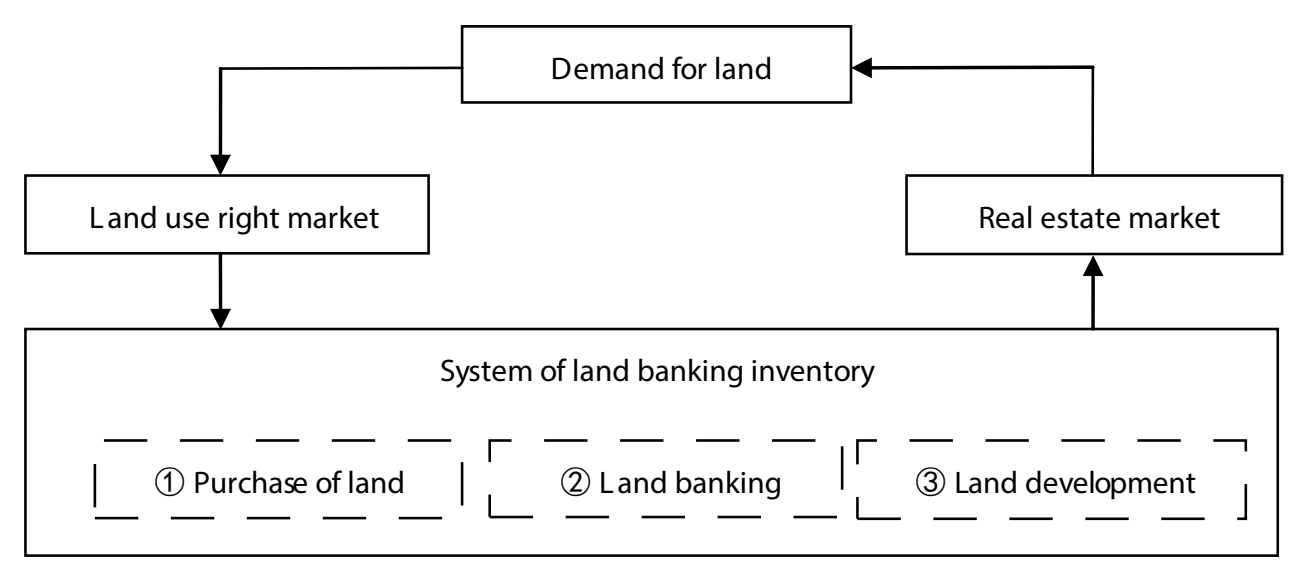

Figure 1. System of land banking inventory for land development enterprises 
According to the land economics (Harvey and Jowsey, 2003), demand for land is derived demand. Land has value only because it enables production or consumption of goods and services. As to the private land development enterprises, land provides space and location for residential development. If demand for residential development increases, there will be increase in demand for land as well. On the contrary, if demand for residential development decreases, there will be decrease in demand for land also. What's more, the demand for land today is based on the prediction of the demand for the housing tomorrow (Tsoukis and Alyousha, 1999). Therefore, the amount of land banking at one period depends on the expected amount of housing selling at next period.

\section{Land development}

Land development should be matched with the growth speed of real estate enterprises. At different development stages, land development scale increases as the growth index increases. When an enterprise stabilized and matures, its land banking scale can be controlled in a certain reasonable level. The growth of housing selling, to a certain extent, reflects the growth speed of a real estate enterprise, and therefore in practice there are a lot of enterprises using the growth of housing selling to calculate and predict land banking scale (Wang, 2008). So, this paper employs the growth of housing selling to represent the growth speed of real estate enterprises.

Real estate development is a multifaceted business which include activities ranging from the renovation and re-lease of existing buildings to the purchase of raw land and the sale of improved parcels to others (Peiser and Frej, 2003). Developers will usually "purchase a tract of land, determine the marketing of the property, develop the building program and design, obtain the necessary public approval and financing, build the structure, and lease, manage, and ultimately sell it. Purchase of raw land is the starting of the real estate development cycle" (Peiser and Frej, 2003). In order to actualize sustainable development of the real estate projects, developers pursue moderate quantity of land banking. One key question asked by researchers is the factors that determinant of developers' decision making on land banking. There are two kinds of view from the literatures concerned the factors. Liu and Ren (2008) pointed out that cost of carry, mainly includes loan rate and financing cost, and expected return are the two factors. While other researchers argued that enterprise life cycle and the firm growth rate affect the land banking (Wang, 2008; Zhu, 2009; White, 1986).

As a result of the regulative limitation of relevant laws that approved land will be retrieved if no promised development initialed in two years, the speculative land banking activities will lead to policy risk and damage to corporate reputation. In other word, the real estate develop enterprises should keep land banking scale controlled in an acceptable policy risk level, and in a reasonable pace with enterprise developing growth and sales capacity, in order to promote the sustainable development of the enterprises.

The marketing principle of real estate enterprises is "low buy, high sell", i.e. to increase land banking scale at a relatively low price at market depression period (usually along with strict macro policies), and to keep a stable land banking scale and accelerate the land developing speed when the market goes up. However, according to the politic risks, it's difficult to adjust the business strategies to keep in pace with the market cycle. Therefore the safety range of land banking scale becomes important to the real estate enterprises to keep sustainable development in the context of policy fluctuation and market changes. 


\subsection{Quantitative decision making model on land banking}

According to the above analysis, the land banking scale of real estate enterprises at current period depends on the prediction of the selling growth at next development cycle. That is to say, the prediction of the land selling growth of next development cycle determines the decision-making of current land banking strategy. Different real estate enterprises have different growth abilities; therefore their land selling growth varies. Furthermore, considering that land selling growth is usually affected by external factors such as policy risk, the monthly land selling growth of real estate enterprises can be regarded as a random variable.

By using the plot ratio, the housing sales area can be transformed into land selling area. According to the Pulte's experience, land banking should be controlled in a safe level to ensure the land reservation for the development of next two to three years (Chengdu ZhengHe Real Estate Co., LTD consultant department, 2009), the safety range of land banking scale in order to maintain sustainable development of real estate enterprises is built in the following formula:

$$
\begin{aligned}
& \frac{\sum_{k=1}^{24} \prod_{i=1}^{k} S_{0}(1+x(i))}{y} \leq L \leq \\
& \frac{\sum_{k=1}^{36} \prod_{i=1}^{k} S_{0}(1+x(i))}{y} .
\end{aligned}
$$

Real estate enterprises have to develop certain land area to provide enough house sales area at next development cycle. The current quota of land area that should be developed is shown as follow:

$$
\Delta L=\frac{S_{0} \sum_{i=1}^{t}[1+x(i)]}{y}
$$

where: $L-$ new land banking scale (unit: $10 \mathrm{k} \mathrm{m}^{2}$, i.e. $10000 \mathrm{~m}^{2}$ ); $S_{0}$ - current housing sales area (unit: $10 \mathrm{k} \mathrm{m}^{2}$ ); $t$ - the development cycle including land pursuit, land development and housing sales (unit: month). Generally, it's 24 to 36 months, according the specific situation of a real estate enterprise; $x(i)$ - monthly land selling growth on $i^{\text {th }}$ month, $i=1,2, \ldots, t ; y-$ average plot ratio.

Through formula (1) and (2), this paper formulates the quantitative decision making model on land banking for private land development enterprises. What's more, variable $x(i)$ and $\mathrm{y}$ in the model are uncertain due to the existence of various risks. When the model is used for individual private land developer, probability distribution of Variable $x(i)$ and $y$ should be examined with its data.

\subsection{The Monte Carlo method}

The Monte Carlo method is a powerful tool in many fields of mathematics, physics and engineering, and recently decision makings in real estate studies (Lima Jr. and Alencar, 2008; Khamkanya and Sloan, 2008; Huh et al., 2012). The Monte Carlo method was also applied by Ginevičius and Zubrecovas (2009) in their study on criteria for investing in real estate projects. The algorithms based on the Monte Carlo method is able to give statistical estimates for any linear functional of the solution by performing random sampling of a certain random variable (r.v.) whose mathematical expectation is the desired functional (Atanassov and Dimov, 2008). The Monte Carlo method was developed in 1949, when the paper of Metropolis and Ulam (1949) was published, although some authors point to earlier dates. The development of modern computers, and particularly parallel computing systems, provided fast and specialized generators of random numbers and gave a new momentum to the development of Monte Carlo algorithms. 
There are two main directions in the development and study of Monte Carlo algorithms. The first is Monte Carlo simulation and the second is Monte Carlo numerical algorithms. This paper would adopt Monte Carlo simulation to simulate the decision making on land banking for real estate developers. Monte Carlo simulation is used as a tool for choosing one of many different possible outcomes of a particular process. It could be considered as a method for solving probabilistic problems using some kind of simulations of random variables or random fields. Using Monte Carlo simulation we could obtain an unbiased and consistent point estimator (Usábel, 1998).

Generally, Monte Carlo simulation is performed in the following steps:

Step 1: Determine the distribution function for each uncertainty thorough the history data.

Step 2: Allocate a random number for each uncertainty. For each uncertain variable, to generate random number obey the distribution which is determined in the step1. It can change the sample size and the simulating frequency to aggregate accurate rate.

Step 3: According to simulation results, statistic the frequency of occurrence and draw the frequency diagram for obtained utilities.

\section{CASE STUDY}

The simulation is projected based on the case study on China Vanke. Co. Ltd. China Vanke. Co., Ltd is founded in 1984, and its core business in real estate. It is one of the leading enterprises of Chines residential housing business. In 2009, the total housing sales area of Vanke was $6636 \mathrm{k} \mathrm{m}^{2}$, and the total housing sales amount was 63.42 billion RMB ( 1 US Dollar $\approx 6.39 \mathrm{RMB}$ ), with growth rate of $19.1 \%$ and $32.5 \%$ over the same period last year respectively (Zeng, 2006). Due to Vanke's recent successes, Vanke's land banking strategy of "fast-in-fast-out" has been imitated by many other Chinese real estate enterprises. Therefore, this paper uses Vanke as the case to establish a quantitative decision making model of land banking based on Monte Carlo Simulation Method, which is perceived to be able to improve the decision making process of real estate enterprises. Similar to past study by Suhobokov (2007), Matlab was used to conduct the Monte Carlo Simulation.

\subsection{Probability distribution of sales growth rate and that of plot ratio}

\section{Sales growth}

According to the collected data of Vanke's housing sales monthly between January 2007 to April 2010 (see Table 1), the distribution of the data has been analyzed by using dfittool of Matlab. The result shows that $(x+0.0164797) / 0.30016$ obeys $t$ student with parameter 1.89 , where $x$ is the monthly housing sales growth. Furthermore, KolmogorovSmirnov test is adopted to test the goodness of fit, and the result indicates significant distribution fitting ( $h=0, p=0.7053)$. The density graph of the fitted $t$ distribution is shown in Figure 2.

\section{Plot ratio}

The plot ratio of Chinese cities is designed and regulated by the city planning administrative departments. In the determination of the particular plot ratio for a project, the city planning administrative departments mainly relies on the relevant laws and regulations, while considering the overall city planning and ad hoc situations of the project (Zhai, 2006), such as regional position, construction type, and furthermore employ some effective statistical methods. 
Table 1. Vanke's housing sales monthly between January 2007 to April 2010

\begin{tabular}{llll}
\hline Time & Housing sales area & Time & Housing sales area \\
\hline APR.2010 & 63.3 & AUG.2008 & 40.7 \\
MAR.2010 & 63.1 & JUL.2008 & 31.1 \\
FEB.2010 & 25.2 & JUN.2008 & 43.7 \\
JAN.2010 & 62.6 & MAY.2008 & 53.4 \\
DEC.2009 & 55.0 & APR.2008 & 43.2 \\
NOV.2009 & 52.3 & MAR.2008 & 66.8 \\
OCT.2009 & 65.4 & FEB.2008 & 15.7 \\
SEP.2009 & 54.6 & JAN.2008 & 18.5 \\
AUG.2009 & 48.2 & DEC.2007 & 61.7 \\
JUL.2009 & NOV.2007 & 42.3 \\
JUN.2009 & 51.2 & OCT.2007 & 51.6 \\
MAY.2009 & 68.6 & SEP.2007 & 69.2 \\
MAY.2009 & 64.1 & SEP.2007 & 69.2 \\
APR.2009 & AUG.2007 & 62.8 \\
MAR.2009 & 64.1 & JUL.2007 & 36.6 \\
FEB.2009 & 52.7 & JUN.2007 & 56.6 \\
JAN.2009 & 61.4 & MAY.2007 & 53.4 \\
DEC.2008 & 38.9 & APR.2007 & 43.2 \\
NOV.2008 & 21.9 & MAR.2007 & 66.8 \\
OCT.2008 & 53.4 & FEB.2007 & 15.7 \\
SEP.2008 & 35.7 & JAN.2007 & 18.5 \\
\hline
\end{tabular}

Note: (unit: $10 \mathrm{~km}^{2}$ )

Data Source: EMIS



Figure 2. Probability distribution fitting 
According to the relevant laws and regulations and construction experiences, the recommended plot ratio of residential housing is classified into four types (Chen et al., 2011):

$<=1$, as to villatics;

$1.0 \sim 1.2$, as to buildings with 4 to 6 stories; $<2.0$, as to buildings with 7 to 9 stories; $<4.5$, as to buildings with 10 to 30 stories.

Vanke focuses on the business of normal residential housing, mostly 7 to 9 stories. Based on the above analysis, the average plot ratio is assumed to obey a triangle distribution with mean 2.75 and coverage from 1 to 4.5. The distribution is shown in the Figure 3.

\subsection{The process of Monte Carlo simulation}

Assume the development cycle of Vanke is 30 months, thus the current quota of land area that should be developed depends on the housing sales area. According to the quantitative decision making model, the current land banking scale should meet the land demand for housing sales area in 30 months. That is

$$
\Delta L=\frac{S_{0} \sum_{i=1}^{30}[1+x(i)]}{y} .
$$

Then, input the original monthly housing sales area in April 2010, i.e. $S_{0}=63.3$, and run the 10000 times of Matlab simulation. The detailed simulation process is shown in Figure 4.

Based on Figure 4, the steps are explained as below:

Step 1: let $j=1$, initial the original housing sales area $s_{0}=63.3$;

Step 2: generate $36 \times 1$ random variable of land selling growth rate $x(i)$ with $t$ distribution and average plot ratio $y$ with triangle distribution;

Step 3: According to formula (1), calculate the maximum and minimum land bank scale;

Step 4: if $j<10000$ (the total number of simulation times), go to step 2 , else go to step 5;

Step 5: output the statistic result of the safety range of land banking scale.

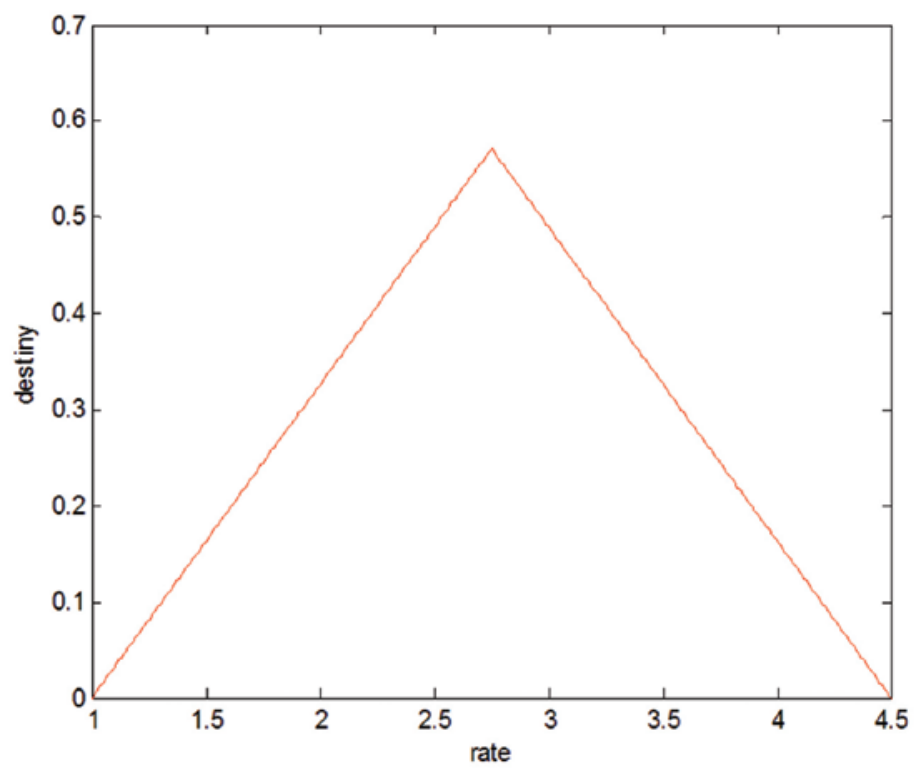

Figure 3. Probability distribution of plot ratio 




Figure 4. Simulation process of land banking decision-making model

\subsection{Result analysis}

Calculated by Matlab, in May 2010, the quota of land area that should be developed is shown in Table 2.

Table 2. Simulation result

\begin{tabular}{llllll}
\hline$L_{\min }$ & \multicolumn{3}{c}{$L_{\max }$} & \multicolumn{3}{c}{$\Delta L$} \\
\hline Mean & Std & Mean & Std & Mean & Std \\
1599.2 & 138.5 & 2024.1 & 81.5 & 145.1 & 32.1 \\
\hline
\end{tabular}

Note: (unit: $10 \mathrm{~km}^{2}$ )

From the simulation result, in May 2010, the land banking quota of Vanke should be controlled in the interval [15992, 20241] $\mathrm{k} \mathrm{m}^{2}$, so that its sustainable development can be effectively managed. Of course, at different stages of the development cycle, the decision of land banking should be different. For example, when the market is going down to recession, it would be better to purchase more land, in particular the maximum of the safety range interval $L_{\max }$; similarly, when the market is going up, Vanke should accelerate the land development plan to acquire the return and control the land banking scale to a lower level, in particular the minimum of the safety range interval $L_{\min }$. On the other hand, in order to provide enough housing for the housing sales in 30 months, in May 2010, the current quota of land area that should be developed should be $1451 \mathrm{~km}^{2}$.

In order to utilize the quantitative decision making model on land banking, the developers should collect the time-series data of housing sales area, the quota of land area developed and land banking quota. Thus, the researchers of the private land development enterprises can compare the simulation results with the real scenarios. The compare will be benefit to the developers to make decision on land banking. 


\section{CONCLUSIONS AND IMPLICATIONS}

The decision making of land banking of real estate enterprises is affected by various external factors, especially the politic risks, and internal variables, such as housing sales growth which presents a certain random distribution. In this paper, the quantitative decision making of land banking based on Monte Carlo Simulation is established and also demonstrated by the case of China Vanke Co. LTD. Through the use of Matlab, this research obtained a fitted distribution for the housing sales growth. Several probability distributions of factors were also drawn from the extant data. The statistical result of simulation finds a safety range interval of land banking for the quantitative decision making of land banking model, which indicates some suggestions for the decision makers of real estate enterprises.

Due to the flexibility of the Monte Carlo Simulation method, some internal or external factors which may be ignored in the demo can be easily added to the model, once the factors can be measured as probability distribution. For example, the capital resource a specific real estate enterprise has possessed will definitely limit its maximum land banking scale.

This research has some important implications. Firstly, it focused on the topic of land banking in China, which is an important topic due to the current growth of real estate industry in China. The economic impacts of real estate industry in China in turn will affect the development of China, and other countries that are heavily depended on China's current economic growth. Secondly, land banking is an important issue for many developing countries as well. This research demonstrated the decisions involved in land banking in China, and other countries can adopt the research approach from this paper to develop relevant decision models for land banking study in their countries. Thirdly, as China begins to open up its economy, especially with its entrant into the World Trade Organizations (WTO), foreign real estate firms will start to invest in China. This research offers some insights into the land banking environment in China, and the decisions that foreign firms need to consider if they enter into China's real estate industry. Lastly, this research applied the Monte Carlo Simulation method to develop a land banking decision model. This is one of the first few studies that have applied the Monte Carlo Simulation approach in studying China's land banking decisions, and can serve as a platform for future studies.

\section{LIMITATIONS AND FUTURE STUDIES}

There are several limitations and future studies that can be recommended. As with other researches, it is not possible for us to consider all the different decision factors involved in land banking. Further research including more factors can be conducted in the future. What's more, if the different stages of the development cycle can be well distinguished, more specific and precise models are perceived to be established based on the quantitative decision making model of this paper. Lastly, future researches can adopt the same approach and study on land banking in different parts of China or different countries, and compare the results with those derived for this research.

\section{ACKNOWLEDGMENT}

This research has received financial support from the Zhi-Jiang Young Scholar Program of Social Science of Zhejiang Province (11ZJQN025YB) and the Natural Science Foundation of China (70803042). The authors would like to thank the funding organizations for the grants. Any remaining mistakes belong to the authors. 


\section{REFERENCES}

Atanassov, E. and Dimov, I. T. (2008) What Monte Carlo models can do and cannot do efficiently?, Applied Mathematical Modelling, 32(8), pp. $1477-1500$.

http://dx.doi.org/10.1016/j.apm.2007.04.010

Atmer, T. (1987) Land banking in Stockholm, Habitat International, 11(1), pp. 47-55. http://dx.doi.org/10.1016/0197-3975(87)90034-8

Carr, J. and Smith, L. B. (1975) Public land banking and the price of land, Land Economics, 51(4), pp. 316-330.

Chen, J., Guo, F. and Wu, Y. (2011) One decade of urban housing reform in China: Urban housing price dynamics and the role of migration and urbanization, 1995-2005, Habitat International, 35(1), pp. 1-8.

http://dx.doi.org/10.1016/j.habitatint.2010.02.003

Chengdu ZhengHe Real Estate Co., LTD consultant department (2009) Thinking of real estatemarch in the uncertainty: be a prepared company. People's Publishing House of Sichuan.

Enders, M. J. (1986) The problem of land banking: a French solution, Environment and Planning $C$ : Government and Policy, 4(1), pp. 1-17. http://dx.doi.org/10.1068/c040001

Evans, A. W. (2004) Economics, real estate and the supply of land. Oxford, UK; Malden, MA: Blackwell Pub.

Fan, Y., Wang, C., Yao, S. and Yu, C. (2009) Feedback mechanism of land reserve and urban planning, Economic Geography, 29(12), pp. 2061-2065.

Flechner, H. L. (1974) Land banking in the control of urban development. New York: Praeger Publishers.

Gimpelevich, D. (2011) Simulation-based excess return model for real estate development: A practical Monte Carlo simulation-based method for quantitative risk management and project valuation for real estate development projects illustrated with a high-rise office development case study, Journal of Property Investment \& Finance, 29(2), pp. 115-144.

http://dx.doi.org/10.1108/14635781111112765

Ginevičius, R. and Zubrecovas, V. (2009) Selection of the optimal real estate investment project basing on multiple criteria evaluation using stochastic dimensions, Journal of Business Economics and Management, 10(3), pp. 261-270. http://dx.doi.org/10.3846/16111699.2009.10.261-270

Harts-Broekhuis, A. and Huisman, H. (2001) Resettlement revisited: land reform results in resource-poor regions in Zimbabwe, Geoforum, 32(3), pp. 285-298. http://dx.doi.org/10.1016/ S0016-7185(00)00032-4

Harvey, J. and Jowsey, E. (2003) Urban land economics. Palgrave Macmillan.

Huang, D. (2010) Land banking mechanism and its effects on city development in China. [Online] Available at: www.hkbu.edu.hk/ curs/ Abstracts\%20and\%20Fullpapers/05/04.doc [accessed 17 August 2010]

Huang, X., Xie, Z., Hu, Z., Tang, M. and Chen, C. (2002) Research on operation and reform of land banking in Nanjing, Social Science in Nanjing, (9), pp. 87-93.

Huh, Y. K., Hwang, B. G. and Joong-Seok Lee, J. S. (2012) Feasibility analysis model for developerproposed housing projects in the Republic of Korea, Journal of Civil Engineering and Management, 18(3), pp. 345-355. http://dx.doi.org/1 0.3846/13923730.2012.698911

Juškevičius, P. (2003) Harmonisation of the Vilnius urban development: Problems and trends of actions, Journal of Business Economics and Management, 4(1), pp. 72-80. http://dx.doi.org/10.10 80/16111699.2003.9636040

Kaklauskas, A., Zavadskas, E. K., Banaitis, A. and Šatkauskas, G. (2007) Defining the utility and market value of a real estate: A multiple criteria approach, International Journal of Strategic Property Management, 11(2), pp. 107-120. http://dx.doi.org/10.1080/164871 5X.2007.9637564

Khamkanya, T. and Sloan, B. (2008) Flexible working in Scottish local authority property: Developing a combined resource management strategy, International Journal of Strategic Property Management, 12(3), pp. 183-202. http://dx.doi. org/10.3846/1648-715X.2008.12.183-202

Lee, Y. S. F. (1988) The urban housing problem in China, The China Quarterly, 115, pp. 387-407.

Leung, B. Y. P., Hui, E. C. M, Tan, J-H., Chen, L. and Xu, W. (2011) SWOT dimensional analysis for strategic planning - the case of overseas real estate developers in Guangzhou, China, International Journal of Strategic Property Management, 15(2), pp. 105-122. http://dx.doi. org/10.3846/1648715X.2011.582745 
Lima Jr., J. D. R. and Alencar, C. T. D. (2008) Foreign investment and the Brazilian real estate market, International Journal of Strategic Property Management, 12(2), pp. 109-123. http://dx.doi. org/10.3846/1648-715X.2008.12.109-123

Liu, H. and Ren, R. (2008) Research on the behavior of land reserve and land biding of developers, China Land Science, 22(12), pp. 11-16.

Ma, X. (2003) The comparison on land reservation and management operating pattern, Huazhong Agritural University, Wuhan, China.

Metropolis, N. and Ulam, S. (1949) The Monte Carlo method, Journal of the American Statistical Association, 44(247), pp. 335-341. http://dx.doi. org/10.1080/01621459.1949.10483310

Peiser, R. B. and Frej, A. B. (2003) Professional real estate development: The ULI guide to the business. $2^{\text {nd }}$ edition. Washington, DC: Urban Land Institute.

Peterson, R. and Silver, E. A. (1979) Decision systems for inventory management and production planning. New York: Wiley.

Strong, A. L. (1979) Land banking: European reality, American prospect. Baltimore: Johns Hopkins University Press.

Suhobokov, A. (2007) Application of Monte Carlo simulation methods in risk management, Journal of Business Economics and Management, 8(3), pp. 165-168. http://dx.doi.org/10.1080/161 11699.2007.9636165

Sun, X. (2007) Strategic comparison of Chines listed real estate enterprises, New Financial Management, 11, pp. 24-27.

Tsoukis, C. and Alyousha, A. (1999) Implications of intertemporal optimization for house and land prices, Applied Economics, 31(12), pp. 1565-1571.

http://dx.doi.org/10.1080/000368499323085

Tse, R. Y. C. (1998) Housing price, land supply and revenue from land sales, Urban Studies, 35(8), pp. 1377-1392. http://dx.doi.org/10.1080/0042098984411

Tu, X., Pu, L., Huang, X. and Jin, X. (2008) Urban land-banking planning: a new instrument to regulate urban land supply-demand of Nanjing city, Chinese Journal of Population, Resources and Environment, 6(2), pp. 18-24.

Usábel, M. A. (1998) Applications to risk theory of a Monte Carlo multiple integration method, Insurance Mathematics and Economics, 23(1), pp. 71-83. http://dx.doi.org/10.1016/S01676687(98)00026-2

Van Dijk, T. and Kopeva, D. (2006) Land banking and Central Europe: future relevance, current initiatives, Western European past experience, Land Use Policy, 23(3), pp. 286-301. http:// dx.doi.org/10.1016/j.landusepol.2004.07.005

Wang, B. (2004) Reflection on land banking mechaism and its legislation basis, West China University of Political Science and Law, Chongqing, China.

Wang, Y. (2008) Land banking and the developmental model of real estate enterprise, China Real Estate, 8, pp. 45-47.

Wang, Y. and Murie, A. (1996) The process of commercialisation of urban housing in China, $U r$ ban Studies, 33(6), pp. 971-989. http://dx.doi.org/10.1080/00420989650011690

White, P. (1986) Land availability, land banking and the price of land for housing: A review of recent debates, Journal of Property Research, 3(2), pp. 101-111. http://dx.doi.org/10.1080/02640828608723904

Wu, F. (1996) Changes in the structure of public housing provision in urban China, Urban Studies, 33(9), pp. 1601-1627. http://dx.doi.org/10.1080/0042098966529

Wu, F. (2001) China's recent urban development in the process of land and housing marketisation and economic globalization, Habitat International, 25(3), pp. 273-289. http://dx.doi. org/10.1016/S0197-3975(00)00034-5

Yang, J. (2006) Risk management in land banking. Tongji University, Shanghai, China.

Yeh, A. G. O., Wu, F. (1996) The new land development process and urban development in Chinese cities, International Journal of Urban and Regional Research, 20(2), pp. 330-353. http:// dx.doi.org/10.1111/j.1468-2427.1996.tb00319.x

Zavadskas, E. K., Ginevičius, R., Kaklauskas, A. and Banaitis, A. (2005) Analysis and modeling of the Lithuanian real estate sector, Journal of Business Economics and Management, 6(3), pp. 135-143. http://dx.doi.org/10.1080/16111699 .2005.9636102

Zax, J. S. (1997) Latent demand for urban housing in the People's Republic of China, Journal of Urban Economics, 42(3), pp. 377-401. http://dx.doi.org/10.1006/juec.1996.2034 
Zeng, X. (2006) Decision on land banking. Unpublished Thesis at University of Central Agriculture, China.

Zhai, G. (2006) Thinking about determination of the plot ratio of the residential land, Planner, 22(12), pp. 74-76.

Zhang, X., Shen, L., Wu, Y. and Fan, L. C. N. (2009) Competitiveness assessment for real estate enterprises in China: A model procedure, International Journal of Strategic Property Management, 13(3), pp. 229-245. http://dx.doi. org/10.3846/1648-715X.2009.13.229-245
Zhang, X., Tan, Y., Shen, L. and Wu, Y. (2011) An alternative approach of competitiveness evaluation for real estate developers, International Journal of Strategic Property Management, 15(1), pp. 10-25. http://dx.doi.org/10.3846/1648 715X.2011.565911

Zhu, X. (2009) The effect of land banking on the performance of listed real estate companies. Unpublished Thesis at Shanghai Finance and Economics University, China. 